\title{
Ambalaj Üzerindeki Sayısal ve Duyusal Bilgi Tercihlerine Göre Makine Öğrenmesi Yaklaşımı ile Tüketicilerin Sınıflandırılması*
}

\author{
Didem TAVLI**, Mehmet Özer DEMIR ${ }^{* * *}$
}

Öz

Günümüzde tüketicilerin satın alma alternatiflerinin artması ile birlikte firmaların tüketicilerin satın alma davranışlarını etkileyen faktörleri incelemesi ve nelere dikkat ettiğini iyi tespit etmesi gerekmektedir. Bu çalışmanın amacl, tüketicilerin satın alma davranışlarını etkileyen pek çok bütünleşik faktörlerden sayısal ve duyusal verilerden tüketiciler tarafından hangisinin tercih edildiğini tespit etmek ve tüketicilerin satın alma davranışlarında ambalaj üzerinde en çok hangi bilgileri dikkate aldığını tespit etmektir. Çalışmada tüketiciler tercih ettikleri bilgi türüne göre makine öğrenmesi yöntemi kullanılarak modellenmeye çalışılmıștır. Araştırmanın verileri anket tekniği kullanılarak toplanmıştır. Örneklem seçimi uygunluk örneklemesi yöntemi kullanılarak yapılmıştır. Çalışmada 18 adet makine öğrenmesine dayalı yöntem kullanılarak tüketiciler sinıflandırılmaya çalıșılmıştır. Elde edilen sonuçlara göre tüketicilerin sayısal ve duyusal bilgi tercihlerine göre iki grupta sinıflandırılabileceği ve makine öğrenmesi algoritmalarından Linear Support Vector Machine (LSVM) yönteminin bu sinıflandırmayı yapan en iyi algoritma olduğu sonucuna varılmıştır. Tüketici sınıflandırmasında büyük veri analizi yöntemlerinin pazarlama alanında kullanılması çalışmanın yazına katkısıdır. Uygulamada ambalaj tasarımcılarının hedef kitlelerinin bilgi ihtiyacı türünün belirlenmesi, ambalaj üzerinde yer alacak bilgilerin tasarlanmasında kullanılabilir.

Anahtar Kelimeler: Ambalaj, Sayısal bilgi tercihi, Duyusal bilgi tercihi, Makine Öğrenmesi, LSVM

JEL Sinıflandırması: M30, M31

\section{The Classification of Consumers Based on the Preferences of the Information Need on the Packaging: The Machine Learning Approach}

\section{Abstract}

The increase in purchasing alternatives forces companies to focus on the factors affecting consumer buying behavior and to determine what they are paying attention to.

\footnotetext{
Özgün Araştırma Makalesi (Original Research Article)

Geliş/Received: 20.01 .2020

Kabul/Accepted: 06.08.2020

DOI: https://dx.doi.org/10.17336/igusbd.674570

* Bu çalışmada, Alanya Alaaddin Keykubat Üniversitesi, Fen Bilimleri Enstitüsü, İşletme Mühendisliği Yüksek Lisans Programı'nda Dr. Öğr. Üyesi Mehmet Özer DEMIR danışmanlığında yürütülen "Tüketicilerin Gıda Ambalajları Üzerindeki Sayısal ve Duyusal Bilgi İhtiyaçlarının Tespiti" (2019) adlı yüksek lisans tezi verileri kullanılmıștır.

${ }^{* *}$ Yüksek Lisans Öğrencisi, Alanya Alaaddin Keykubat Üniversitesi, Fen Bilimleri Enstitüsü, İşletme Mühendisliği ABD, Alanya, Türkiye, E-posta: didemtavli@gmail.com ORCID https://orcid.org/00000002-1565-1848

${ }_{* * *}^{*}$ Dr. Öğr. Üyesi, Alanya Alaaddin Keykubat Üniversitesi, İşletme Mühendisliği Bölümü, Alanya, Türkiye, E-posta: mehmet.demir@alanya.edu.tr ORCID https://orcid.org/0000-0002-5035-0530
} 
This study aims to research consumers' numerical and sensory information preferences and to determine what information the consumers take most on the packaging. In this study, data obtained from the participants' have been studied with machine learning methods according to the information type they prefer. The data of the study were collected using a questionnaire form. Sample selection was done by using a convenience sampling method. In this study, consumers are classified with 18 big data-based machine learning methods. According to the results, the Linear Support Vector Machine (LSVM) method supports the best result. The use of big data analysis methods in marketing is the contribution of this study to the current literature. In practice, determining the type of information needs of the target consumers helps package designers in designing the information to be included in the packaging.

Keywords: Packaging, Digital information preference, Sensory information preference, Machine learning, LSVM

JEL Classification: M30, M31

\section{GíRiş}

Günümüzde süpermarketler tüketim alışverişlerinde söz sahibi konumdadırlar ve bu durum rekabeti üst seviyelere taşımıştır. Süpermarketlerde tüketiciler ürün satın alırken satış elemanları ile değil direk ürünler ile karşı karşıya gelmeye başlamışlardır. Tüketicinin ürün ile karşı karşıya gelmesi demek; tüketicinin direk ambalaj ile karşı karşıya gelmesi ve ambalajın satın alma davranışlarında etkin rol oynaması demektir. Tüketici için ambalaj o anda, firmayı, markayı ve ürünü yansıtmaktadır. Tüketicilerin ise ortalama 25 dakika süpermarkette zaman geçirdiği bilinmektedir. Müșterinin bu ürünlerden ortalama bin tanesini gördügünü ve sadece 14 adet ürünün hafızasında kaldığını belirtilmiştir. Yani; tüketici, her ürün için 2-6 saniye arasında zaman harcamaktadır ve ürün tüketiciyi bu süre içerisinde etkileyebilme yeteneğine sahip olmalıdır. Bu da ancak ambalaj tasarımı ile mümkün olmaktadır (Cahyorini \& Rusfian, 2012; Chandon, 2013; Durmaz, 2009; Mina, 2017).

Tüketicilerin hemen hemen yarısının satın alma davranışını plansız gerçekleștirdikleri yapılan araştırmalarla desteklenmiștir (Dilber, Dilber \& Karakaya, 2012). Araştırmalar tüketicilerin büyük çoğunluğunun satın alma işlemini 10 saniyeden kısa bir sürede karar verdiğini göstermektedir (Mina, 2017). Plansız yapılan alışverişlerde, doğru zamanda doğru yerde bulunan etkili reklam içeren bir ambalajlı ürününün tüketiciyi etkileme olasılığ çok yüksektir. Ambalaj tüketicinin dikkatini çekebilir, ilgisini uyandırabilir ve üzerinde bulunan ürün bilgileri sayesinde değerlendirme yapmasını sağlayabilir. Dolayısıyla tüketici de deneme, satın alma isteği uyandırır (Dilber vd., 2012; Gökalp, 2007; Müderrisoğlu, 2009; Örücü \& Tavşancı, 2011). Yapılan çalışmalar da zaman kısıtlı olduğunda, tüketicilerin hızlı tüketilen ürünleri satın alırken tasarımdaki görsel özelliklere daha fazla önem verdiğini vurgulamaktadır (Dilber vd., 2012; Gökalp, 2007; Müderrisoğlu, 2009; Örücü \& Tavşancl, 2011; Tek, 1999; Yan \& Duclos, 2013). Özellikle hızlı tüketim ürünleri için tüketici hızlı karar vermek zorundadır ve ambalaj markanın imajını desteklemeli, satın alacak kişinin gözünü ve satın alma duygularını kendi üzerine çekmelidir. Yapılan araștırmalarda, Avrupa'da bulunan tüketicilerin \%34'ünün ambalajını beğenmediği ürünlerin yerine başka ürünlere yöneldiğini göstermiștir (Cahyorini \& Rusfian, 2012; Chandon, 2013; Dilber vd., 2012; Durmaz, 2009). Ambalaj tasarımında, kültürlerin dikkat ettiği unsurlar göz önüne alınarak hazırlanan görsel sunum satış başarılarını arttırmaktadır (Chandon, 2013; Durmaz, 2009; Düz, 2012). 
Reklamcılar, akademisyenler, pazarlama uzmanı profesyoneller, tasarımcılar, hemen hemen aynı anlama gelen, ancak kişisel anlatım üslupları ve bakış açısından kaynaklı farklılık gösteren biçimlerde ambalajı tanımlamışlardır. Ambalajı anlamak için öncelikle; ceviz, bezelye, portakal, fındık, yumurta gibi doğadaki ambalajlar incelenmiștir (Mina, 2017). Ambalaj dış sarmalayan nesne, paket ise içindeki nesneyi ve sarmalayan nesneyi tanımlayan bir bütün olarak ele alınmıștır (Cahyorini \& Rusfian, 2012; Erevelles, 1998). Ambalaj ürünleri bir arada tutarak; lojistik, depolama, dağıtım, pazarlama işlemlerinde kolaylık sağlayan aynı zamanda ürünleri koruyan, zarar gelmesini engelleyen metal, kâğıt, karton, cam veya plastik gibi malzemelerden üretilen diş malzemelerdir (Clement, Smith, Zlatev, Gidlöf \& Van de Weijer, 2017; Cowburn \& Stockley, 2005). Reklam ve pazarlama uzmanları ambalajı tanımlarken tasarımın önemini vurgulamıștır, Viswanathan (1996) ambalajı giysiye benzetmiștir, tüketicinin ürünü satın alırken gerekli tüm güzellikleri ürünün üzerinde bulması gerektiğini savunmuştur.

Ambalaj aslında tüketici için satın alma noktasında ürünü temsil etmekte, ürünün piyasada tutundurulmasını da sağlamaktadır (Baştürk, Yıldız \& İnan, 2014). Süpermarketlerde bulunan binlerce ürünün ambalaj olmaksınız satılmaları mümkün değildir. Pratiklik, taşıma ve nakliye kolaylığı ve koruma ambalajın ürün ile birlikte geliştirdiği bazı özelliklerdir. Ambalajın tarihi aslında insanların ihtiyaçları doğrultusunda gelişmiştir. Değisşen toplumlar, rekabetçi piyasa anlayışı, tarihi ve kültürel olaylar, sanat hareketleri, teknolojik buluşlar ve değișen yaşam tarzları gibi gelişmelerin tümünden etkilenerek ihtiyaç haline gelmiştir (Kim, 2017; Kwong \& Wong, 2006; Müderrisoğlu, 2009). Bunun yanında, tüketicilerin yaşam tarzlarındaki değişimler, firma ve marka imajı, kendin seç al, tüketicilerin demografik özellikleri, değişen toplum ve kültür yargıları gibi daha birçok etmen ambalajın pazarlama aracı olarak görülmesine yol açmıştır (Örücü \& Tavşancı, 2011; Tek, 1999).

Endüstriyel üreticiler mamullerini tüccarların satabilmesi amacıyla, cazip şekilde paketleyebileceklerini keşfetmişler ve ambalajları bu amaçla kullanmaya başlamışlardır (Kwong \& Wong, 2006). Tüm gelişmeler sonucunda ambalaj satış sürecinin temel ve ayrılmaz bir parçası haline dönüşmüştür (Ak, 2009). Ambalaj ürünün ömrünü uzatırken grafik ve yapısal tasarım nitelikleriyle süpermarket rafında benzerleriyle rekabete girerek pazarlama konusundaki yerini almıștır (Müderrisoğlu, 2009). Bu sayede etkili bir satış yöntemi aracı olarak kullanılması da kaçınılmazdır. Ambalaj tüketicinin satın alma davranışını ve tüketimini doğrudan etkilemektedir (Mina, 2017; Tek, 1999). Ürünün satışına katkıda bulunan ambalaja, bu sebeplerden dolayı sessiz satış elemanı da denmektedir.

Günümüzde ürün farklılaştırmak oldukça zor ve karıșlk bir hale gelmiştir. Ürün farklılaştırmak konusunda da ürün ambalajlarına aslında çok fazla görev düşmektedir. Ambalajın bir ürünü bir başka ürün ve markadan ayırmak konusunda her zaman yardımı olmuştur ve etiketler de bu konuda aslında tüketiciyi yönlendirmektedir (Ak, 2009; İlhan, 2016; Topuzoğlu, Hıdıroğlu, Ay, Önsüz \& İkiışık, 2007). Genelde tüketicinin bir ürünü tercih etmesinin sebepleri arasında marka vaatleri mevcuttur. Ambalaj tasarımının asıl amacı bir görsel yaratmaktan çok, stratejik amaçları satılabilir somut şeylere dönüștürerek, tasarımcının masaya koyacağı yetenek ve deneyimle ambalajın güçlü ve güzel görünmesini sağlamaktır (Dilber vd., 2012; Durmaz, 2009; Gökalp, 2007). Günümüzde ambalaj, ünlü markaların logolu ve grafik tarzlarını taşıyan, insanlar tarafından onurla ve zevkle taşınan yürüyen reklamlar haline gelmiștir. Ambalaj sosyal açıdan kabul görmüş, kendini beğendirir, albeni geliştirir hale gelmiştir (Durmaz, 2009; Düz, 2012; Örücü \& Tavşancl, 2011).

Ambalaj tüketici ile iletişim kurma fonksiyonunu da yerine getirmektedir. $\mathrm{Bu}$ iletişim ancak bilgi verme fonksiyonu aracı ile kurulabilir. Ürünün adı ve logosu, ürünün materyali, üretici adres ve bilgileri, ürünün son kullanma tarihi, ürünün içeriğinde 
bulunan maddeler, ürün miktarı ambalaj üzerinde yer alması gereken zorunlu bazı bilgilerdir. Dökme ambalajlı ürünlerde çoğu zaman miktarı, fiyatı ve kalitesi hakkında müşterinin kafasında soru ișareti ve güvensizlik olabilir (Mina, 2017; Tek, 1999; Underwood \& Klein, 2002).

Ambalaj tasarımının tüketiciyle iletişimi öznel ve nesnel olmak üzere iki başlıkta toplanmıştır. Öznel bilgilendirme; marka, renk biçim gibi unsurlarla tüketiciyi bilgilendirme anlamına gelirken, ambalajın içindeki ürünün niteliğine, yapısına ilişkin bilgilendirme nesnel bilgilendirme olarak adlandırılır (Cahyorini \& Rusfian, 2012; Chandon, 2013; Durmaz, 2009). Tüketicilerin tepkilerine, tutumlarına göre nasıl tasarım yapılacağı üç bölümde incelemiştir. İçsel tasarım; bir ürünün nasıl göründüğü, ilk andaki görsel etkisi. Davranışsal tasarım; nasıl çalıștığını ve kullanım talimatı ile ilgili tüketici deneyimlerini önemseyen tasarımdır. Düşünsel tasarım; kendini bulma, tüketici anılarına, önceki deneyimlerine yapılacak göndermeler ve çağrışımlar olarak adlandırılmaktadır (Chandon, 2013; Durmaz, 2009; Düz, 2012). Tüm bu çalışmalar ve sınıflandırmalar göz önüne alındığında, grafik tasarım açısından ambalaj tasarımı iletişimi iki başlık altında değerlendirilebilir; görsel ve duyusal çekicilik işlevi, bilgilendirme ve ikna etme işlevi (Cahyorini \& Rusfian, 2012; Chandon, 2013; Dilber vd., 2012; Durmaz, 2009).

Ambalaj üzerinde yer alan bilgiler, mantıklı sözcükler ve sayılardan olușurken, şekillerden, renklerden ve grafik yorumlarından geçen diğer duyusal boyut mantık düzeyinden atlayarak direk duygulara hitap etmektedir (Carrillo, Varela \& Fiszman, 2012; Clement vd., 2017; Odumeru vd., 1997). Yiyecek ambalajlarında bunun örnekleri en güzel şekilde görülebilir; Bilgilendirme tasarım yapısının arka planında kalır ve sadece bilgi kendini gösterir (Durmaz, 2009; Edell \& Burke, 1987; Gökalp, 2007; Ramaprasad \& Hasegawa, 1992).

$\mathrm{Bu}$ çalışma tüketicilerin rakamsal bilgi tercih edenler ve duygusal bilgi tercih edenler olarak iki gruba ayrıldıkları varsayımı üzerine kuruludur. Her ne kadar tüketiciler bir ürünü beğendikleri için satın aldıklarını beyan etseler de tüketicilerin bilgi tercihlerine uygun tasarımdaki ambalajlı ürünü tercih ettikleri varsayılmış ve hedef tüketicilerin bilgi tercihlerinin nasıl belirlenebileceği çalışmada araştırılmıştır. Araștırmada katılımcılar Sayısal Bilgi Tercihi (Preference for Numerical Information: PNI) (Viswanathan, 1993) ve Bilgilendirici ve Duyusal Bilgi Tercihi (Informational and Transformational Ad Content: ITAC) (Aaker \& Norris, 1982; Puto \& Wells, 1984) seviyelerine göre sinıflandırılmıştır.

Pazarlama iletişiminin geleceği mobil uygulamalara ve online pazarlamaya kaymaktadır (Gavilan, Avello \& Abril, 2014). İşletmeler online pazarlamaya kaydıkça pazarlamacıların analiz edebilecekleri veri miktarı büyük miktarlara ulașmıștır. Klasik istatistiksel yöntemler (aritmetik ortalama gibi) bu kadar büyük bilgiyi analiz etmekte yetersiz kalmaktadırlar. Bu durum makine öğrenmesi ve/veya veri madenciliği gibi yöntemlerin kullanılmasını gerekli kılmaktadır. Bu çalışmada tüketicilerin ambalaj üzerindeki bilgi tercihlerinin analizinde makine öğrenme algoritmalarının kullanılabileceğini göstermektedir.

\section{SAYISAL BİLGİ TERCIHİ ve DUYUSAL BİLGI TERCïHİ}

Sayısal bilgi tercihi (PNI), sayısal bilgiyi kullanmaya ve sayısal bilgi içeren düşünmeye meyilli olmayı ölçen bir yapıdır. Yazında sayısal bilgileri kullanma yeteneği ve istatistik ve matematik gibi sayısal bilgileri içeren alanlara yönelik tutumlar incelenmiştir (Alken, 1974; Kiss, 2018; Malik, 2018; Wise, 1985). Araştırmacılar sayısal bilgiler içeren çeşitli ortamlarda sayısal bilgileri kullanma becerisine göre sayısal bilgi tutumlarını tanımlamış ve ölçülmüşlerdir. Günlük yaşamda sayısal işlemler kullanmayı okuryazarlıkla paralel olarak incelemişler ve sayısal bilgileri anlama seviyesi üzerinde çalışmışlardır. Bu yaklaşımı benimseyen araştırmacılar sayısal işlemleri, günlük hayatta ihtiyaç duyulan 
Didem Tavlı, Mehmet Özer Demir, “Ambalaj Üzerindeki Sayısal ve Duyusal Bilgi Tercihlerine Göre Makine Öğrenmesi Yaklaşımı ile Tüketicilerin Sınıflandırılması”, İstanbul Gelişim Üniversitesi Sosyal Bilimler Dergisi, 8 (2), Ekim 2021, ss. 337-350.

matematiksel bilgi talebinin karşılanması yanı sıra nicel bilgilerin anlaşılması ve değerlendirilmesi olarak çalışmışlar ve sayısal bilgiyi bir yetenek olarak ele almışlardır. Ancak sayısal işlem kavramının hesaplama ile ilgili becerilerden daha geniş olduğunu ve hem yetenek hem de tutum içerdiğini, bu nedenle sayısal bilgi tercihinin günlük yaşamda sayısal bilgilerle ilgili sadece matematik ișlem yapabilme ve anlama yeteneğini değil sayısal bilgiye yönelik tutumu içermesi gerektiği öne sürülmüștür. Sayısal bilgiye yönelik temel bir tutum ya da eğilimi ölçmeye yönelik ilk ölçek Viswanathan tarafından geliştirilmiştir (Viswanathan, 1993, 1994) ve diğer araştırmacılar tarafından geçerli ve güvenilir bir ölçek olduğu ortaya konulmuştur (Alkhateeb \& Abed, 2002; Smith \& Drumming, 2004). Viswanathan, sayısal bilgiye yönelik tutumu ayrı ve farklı bir alan olarak incelemenin önemini vurgulamıș ve yapının çeşitli ortamlarda uygulamaları olduğunu iddia etmiştir. Sayısal bilgi ihtiyacına sadece matematik işlemlerini yapmak ve/veya anlamak için değil, aynı zamanda insanların kararlarını etkileyen bir tutum olarak yaklaşmıştır. Sayısal bilgi tercihi (PNI) aslında bir kişilik özelliği olabilir, PNI'nın diğer yapılarla iliş̧kisini inceleyen çalışmalar PNI'nın kesinlik ihtiyacının bir sonucu olabileceğini, muğlaklık içeren durumlarla PNI'nın negatif korelasyona sahip olduğunu, kesinlik ile pozitif korelasyona sahip olduğunu ve birçok alternatif arasında bir sıralama yapma ihtiyacı ile ve biliş ihtiyacı ile pozitif yönlü bir ilişkisi olduğunu göstermektedir (Viswanathan, 1993).

PNI'nın potansiyel etkisi karar alma aşamasında sayısal bilgilerin kullanımını gerektiren durumlarda önem kazanmaktadır. PNI, satın alma kararı aşamasında karar vermeyi yönlendirmek için kullanılabilecek önemli tanı bilgileri sağlar. Tüketici satın alma kararının verildiği ortamlarda, sayısal bilgiler genellikle ambalajlarda bulunan besin değerleri, ürünler hakkında istatistikler ve sayısal derecelendirmeler ve pazarlamacılar tarafından ambalaj üzerine aktarılan ürün hakkındaki teknik bilgilerden oluşur.

Her ambalaj bilgi içerir, bu bilgiler aslında marka hakkında bir fikir verirler. Ambalaj üzerinde yer alan bilgiler ikiye ayrılabilir; bilgilendirici (sayısal) bilgiler (informational content-IC) ve duyusal/dönüșümsel (transformational content-TC) (Puto \& Wells, 1984). Ambalaj üzerindeki sayısal bilgiler doğruluğu sınanabilir ve mantıksal çerçeveye uygun bilgiler olduğundan markanın değerlendirilmesinde daha yüksek güven sağlarlar. Ambalaj üzerinde sayısal bilgilerin bulunmasının amacı tüketiciyi bilgilendirmektir, ancak eğer hedef alınan tüketiciler yani hedef kitle bu sayısal bilgileri anlayıp yorumlayabiliyorsa sayısal bilgilendirme işe yarar. Bu nedenle aslında önemli olan ambalajın üzerinde yer alan bilgiler değildir, önemli olan tüketicilerin hangi bilgilerin farkına vardığı, anladığı ve/veya yorumladığıdır.

Diğer yandan ambalajın üzerinde bulunan duyusal (veya dönüşümsel) bilgiler tüketicilerin geçmiş deneyimleri gibi marka ile etkileşimlerinden kaynaklanırlar ve tüketiciler marka ile deneyimlerini duyusal değerlendirmeye "dönüştürdüklerinden" dolayı bu adla adlandırılırlar. Duyusal bilgiler kavramı pazarlama alanındaki birbirinden ayrı üç farklı çalışma alanına dayanır; duygular (emotions), şartlı koşullandırma (conditioning) ve güdüleme (motivation) (Puto \& Wells, 1984). Duyusal bilgi, herhangi bir mantığa, sayısal öncelik veya üstünlük sıralamasına bağlı değildir, ambalajın üzerinde yer alan duyusal bilgiler tüketicinin marka hakkında ne hissettiği ile ilgilidir. Ünlülerin pazarlama iletişiminde kullanılması yolu ile onların sahip oldukları özelliklerin markaya aktarılması duyusal bilgiye örnek verilebilir (Lord \& Putrevu, 2009). Sayısal bilgilerden ayrı olarak, ambalaj üzerinde yer alan duyusal bilgilerin tüketicilerde daha sıcak, daha heyecan verici, daha eğlenceli gibi marka ile ilgili tutum değişikliklerine yol açması hedeflenir. Duyusal bilgiler ruh halini, duyguları, hisleri ve/veya imajı etkilemelidir, duyusal bilgilerin bilişsel bir dayanağı olmak zorunda değildir. Her ne kadar sayısal ve duyusal bilgiler birbirlerini tamamen dışlamasalar, uygulamada birbirini destekleyecek şekilde kullanılırlar. 
Araştırmacılar farklı kültürlerdeki tüketicilerin farklı sayısal ve duyusal bilgi tercihleri olduğunu göstermişlerdir (Cui, Liu, Yang \& Wang, 2013). Ambalaj tasarımında bilgi önem sıralaması ve hiyerarşik sıralaması yapılırken hedef tüketici kitlesinin algısı önemlidir (Durmaz, 2009; İlhan, 2016; King \& Meiselman, 2010). Doğru tasarlanan ambalaj, tüketici zihninde sağlam ve ihtiyaçlarını karşılayan bir yapı sergileyerek satış görevini en doğru şekilde yerine getirerek tüketiciyi ikna edecektir (Bendegül \& Bulduk, 2003; Durmaz, 2009; Kim, 2017).

Hedef tüketicilerin ambalaj üzerindeki bilgileri ne ölçüde yorumlayabilecekleri ve kullanabileceklerinin bilinmesi hedef kitle ve kamuoyu ile iletişimin tasarlanmasında pazarlamacılar için önemlidir. Örneğin hedef alınan tüketiciler sayısal besin değeri bilgilerini yetersiz seviyede kullanıyor olabilir, PNI hedef kitlenin sayısal bilgi tercihlerinin ölçülmesi ile ambalajlarda bulunması gereken bilgi miktarı ve içeriğinin belirlenmesi konusunda açıklayıcı bilgiler verebilir. Veya hedef kitle duyusal bilgi ihtiyacı (TC) bakımından baskın eğilime sahip ise sayısal bilgi kullanımını basitleștiren sayısal ürün bilgilerini sunma yollarını geliştirme çabaları için tanısal değer taşıyabilir (Fennis, Das \& Fransen, 2012). Perry, Motley, and Adams Jr (2016) hukuki yasaların finansal reklamlarda haksız rekabeti önlemek amacıyla doğru sayısal bilgilerin verilmesini zorunlu kılmasına rağmen birçok pazarlama iletişimi mesajının tüketicileri satın almaya ikna etmek için tüketicilerde duyguları ve hisleri harekete geçirmeyi amaçlayan duyusal bilgi içerdiğini göstermişlerdir.

\section{YÖNTEM}

\section{a. Araştırmanın Amacı ve Önemi}

Bu çalışmanın amacı, tüketicilerin satın alma davranışlarını etkileyen pek çok bütünleşik faktörlerden sayısal ve duyusal verilerden tüketiciler tarafından hangisinin tercih edildiğini tespit etmek ve tüketicilerin satın alma davranışlarında ambalaj üzerinde en çok hangi bilgileri dikkate aldığını tespit etmektir. Sayısal bilgi tercihi düşük tüketiciler, sayısal ürün bilgilerini göz ardı edebilirler veya yanlıș değerlendirebilirler. Farklı PNI ve TC düzeylerine sahip tüketiciler için duyusal bilgiler ile birlikte sayısal bilgilerin hangi oranlarda birlikte sunulacağının belirlenmesi için de hedef kitlenin PNI ve TC seviyelerinin belirlenmesi gerekmektedir (Ju \& Park, 2015).

\section{b. Araştırmanın Evreni ve Örneklemi}

Antalya ilinin, Alanya ilçe merkezinde araştırma gerçekleștirilmiştir. Örneklem seçimi uygunluk örneklemesi yöntemi kullanılarak yapılmıştır. Araștırma dizaynı, aynı soruları içeren ancak farklı görseller sunan 2 adet anketin tüketiciler tarafından doldurulmasıyla gerçekleşmiştir. Ankete katılanların sayısal ve duyusal anketlere eşit oranda katılmasına çalıșılmıştır. Antalya'nın nüfusu 2,288 milyon, Alanya'nın nüfusu ise 312.319 olup, merkezde ise ortalama 155 bin kişi bulunmakta, anket 310 kişiye ulaşllıp uygulanmıştır.

\section{c. Uygulama ve Veri Toplama Aracı}

Anket soruları 3 bölümden oluşmaktadır; A grubu (PNI) 20 sorudan, B grubu (ICTC) soruları sayısal ve duyusal bilgi ihtiyaçlarını ölçmek amacıyla hazırlanmıştır ve toplamda 23 adet soru içermektedir. A Grubu insanların sayısal bilgi ihtiyaçlarını ölçmek için kullanılmış. B grubu sorular ise 2 adet hazırlanmış ambalaj türünden; duyusal ve sayısal bilgiler içeren, tüketicilerin tercihlerini belirlemek için hazırlanmıştır. Anket soruları 7'li likert ölçeği tipi sorulardan oluşmaktadır; (1) kesinlikle yanlıș ve (7) 
Didem Tavlı, Mehmet Özer Demir, “Ambalaj Üzerindeki Sayısal ve Duyusal Bilgi Tercihlerine Göre Makine Öğrenmesi Yaklaşımı ile Tüketicilerin Sınıflandırılması”, İstanbul Gelişim Üniversitesi Sosyal Bilimler Dergisi, 8 (2), Ekim 2021, ss. 337-350.

kesinlikle doğru olmak üzere aralıklı cevaplardan oluşmaktadır. Elde edilen veriler Matlab programı kullanılarak elektronik ortamda sayısal veriler haline getirilmiştir.

\section{d. Demografik Bulgular}

Araştırmaya toplam 310 kiși katılmıștır. Katılımcıların 177'i kadın, 133'ü erkektir. Katılımcılar en düşük 11, en yüksek 61 yaşındadır ve ortalama yaş 27, medyanı 26 olarak hesaplanmıștır. Katılımcıların \%2,6'sı ilkokul, \%31,3'ü ortaokul, \%29,7'si lise, \%3,2'si önlisans, \%33,2'si Lisans mezunudur. 154 katılımcı duyusal, 156 katılımcı ise sayısal anketi cevaplamıştır.

\section{e. Analizler}

Analizlerde büyük veri yöntemlerinden makine öğrenmesi kullanılmıștır. Bu amaçla ilk olarak veri setinin araştırmada kullanılan Matlab 2018 programına aktarılması için gerekli düzenlemeler yapılmıștır. Çalışma madde bazlı da yapılabilirdi, ancak yorumlama kolaylığı sağlaması açısından maddeler yazın ile uyumlu şekilde boyutlara ayrılmış ve her bir boyutu temsil eden bir aritmetik ortalama hesaplanmıștır. Katılımcıların anket türü (Duyusal/Sayısal) sınıflandırma değișkeni olarak ikili (binary) değişken olarak analize sokulmuştur. Araştırmada PNI (sayısal bilgi tercihi), IC (Informational Content) ve TC (Transformational Content) değişkenleri ile sınıflandırma yapılmaya çalışılmıștır.

Analizlerin ikinci aşamasında Matlab programına aktarılan veri setinden veri setinin \%25'i makine öğrenmesinde kullanılmak üzere belirlenmiştir. Makine öğrenmesi ile ayrılan alt örneklem baz alınarak makine öğrenmesi algoritmalarından tüketici tercihlerini en iyi sınıflandıran analiz yöntemi belirlenmeye çalışılmıştır. Makine öğrenmesi modelleri içerisinde en iyi sınıflandırma yöntemi olarak Linear Support Vector Machine (Linear SVM) yöntemi olduğu görülmüştür (Tablo 1). Doğrulama sonuçları yüzde olarak yöntemlerin ne kadar başarılı bir şekilde sınıflandırma yaptıklarının ölçütüdür. Linear SVM yöntemi tüketicileri \%71,4 oranında doğru olarak sınıflandırabilmektedir.

\begin{tabular}{|cl|l|}
\hline Yöntem & $\begin{array}{l}\text { Doğrulama Sonuçları } \\
\text { (Validation Results) (Yüzde) }\end{array}$ \\
\hline 1. & Fine Tree & 55,8 \\
\hline 2. & Medium Tree & 58,4 \\
\hline 3. & Coarse Tree & 54,5 \\
\hline 4. & Linear Discriminant & 70,1 \\
\hline 5. & Quadratic Discriminant & 68,8 \\
\hline 6. & Logistic Regression & 70,1 \\
\hline 7. & Linear SVM & $\mathbf{7 1 , 4}$ \\
\hline 8. & Quadratic SVM & 63,6 \\
\hline 9. & Cubic SVM & 58,4 \\
\hline 10. & Fine Gaussian SVM & 54,5 \\
\hline 11. & Medium Gaussian SVM & 50,6 \\
\hline 12. & Coarse Gaussian SVM & 68,8 \\
\hline 13. & Fine KNN & 63,6 \\
\hline 14. & Medium KNN & 59,7 \\
\hline 15. & Coarse KNN & 66,2 \\
\hline 16. & Cosine KNN & 54,5 \\
\hline 17. & Cubic KNN & 57,1 \\
\hline 18. & Weighted KNN & 58,4 \\
\hline
\end{tabular}

Tablo 1. Makine Öğrenmesi Yöntemleri ile Sınıflandırma Sonuçları. 
Linear SVM yöntemi grafik içerikli ambalajı içeren anketi cevaplayan tüketicilerin \%70'ini doğru tahmin etmekte, \%30'unu yanlış sınıfa dâhil etmektedir. Sayısal içerikli ambalajı cevaplayanların \%73'ünü doğru tahmin etmekte \%27'sini yanlış tahmin etmektedir (Tablo 2).

\begin{tabular}{|c|c|c|c|}
\hline \multirow{2}{*}{ 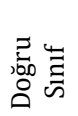 } & Sayısal & $70 \%$ & $30 \%$ \\
\hline & Duyusal & $27 \%$ & $73 \%$ \\
\hline \multicolumn{2}{|c|}{ Doğru tahmin değeri } & $\% 70$ & $\% 73$ \\
\hline \multirow{3}{*}{\multicolumn{2}{|c|}{ Yanlış tahmin değeri }} & $\% 30$ & $\% 27$ \\
\hline & & Sayısal & Duyusal \\
\hline & & \multicolumn{2}{|c|}{ Tahmin Sinıfi } \\
\hline
\end{tabular}

Tablo 2. Tahmin edilen doğru/yanlış oranları

SVM modellerinde ayrım çizgisinin belirlenmesi önemlidir. Ayrımın hangi değişkenler üzerinden yapıldığını incelemek amacıyla saçılma diyagramları incelenir. Saçılma diyagramları çok boyutlu olarak incelenebilse de yorumlaması zor olmaktadır, bu nedenle çalıșmada ikișerli incelemeler tercih edilmiștir (Șekil 1, Șekil 2, Șekil 3).

Şekil 1'de saçılma diyagramında Linear SVM yönteminin iyi bir ayrım yapamadığı görülmektedir. İyi bir ayrıșma örneği Șekil 2 ve șekil 3'te verilmiștir. Şekil 3'te verilen saçılma diyagramı ideale yakın bir örnek sunmaktadır. Grafik bazlı hazırlanan ambalaj anketini cevaplayanlar "daire" ile sayısal bazlı ambalaj anketini cevaplayanlar "üçgen" ile ifade edilmişlerdir. Saçılma diyagramı grafik bazlı anketi cevaplayan katılımcıların duyusal bilgi boyutuna (TC) doğru yaklaștıklarını, sayısal bilgi içeren ambalajı tercih eden katılımcların ise sayısal bilgi boyutuna (IC) doğru yaklaștıklarını göstermektedir. Şekil 3 incelendiğinde, TC tercih edenlerin 1 en düşük 7 en yüksek değeri almak üzere 7 noktalı bir ölçek üzerinde 4-4,5 bandının üzerinde yer aldıkları, bu bandın altına inmedikleri görülmektedir. 4-4,5 bandı duyusal bilgi tercih edenler ile etmeyenler asrındaki ayrım çizgisini oluşturmaktadır. Ancak sayısal bilgi tercih edenler için bu ayrım net değildir, sayışan bilgi terch edenler 7 noktalı likert tipi ölçekte yaklaşık olarak 3 ile 5 arasında değişkenlik saçılmaktadırlar. Bu sonuç sayısal bilgi tercihinin ne çok düşük ne de çok yüksek olmadığı, ortalama bir seviyede seyrettiği şeklinde yorumlanabilir.

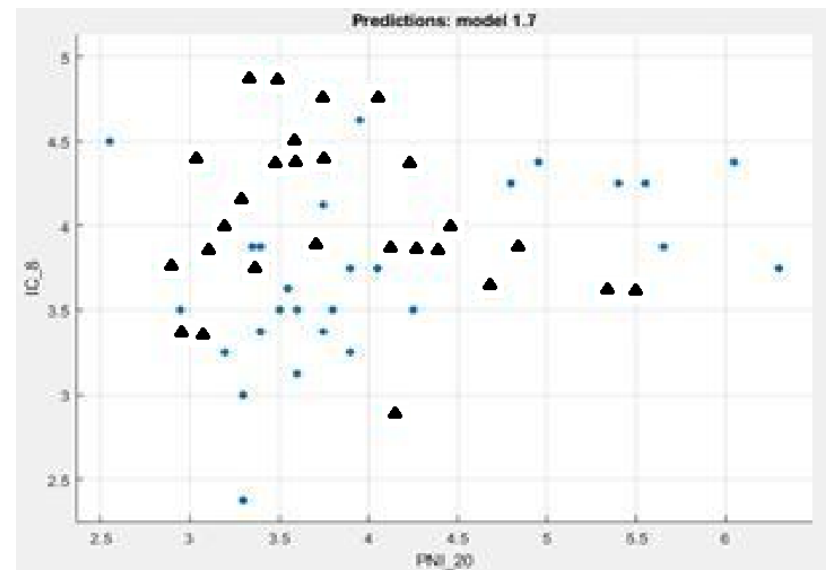

Şekil 1. PNI ile IC Saçılma Diyagramı 


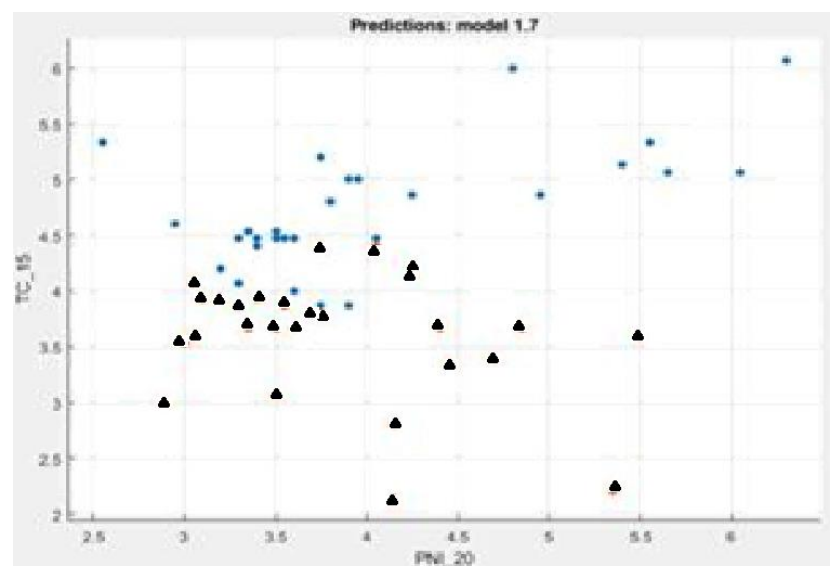

Şekil 2. PNI ile TC Saçılma Diyagramı

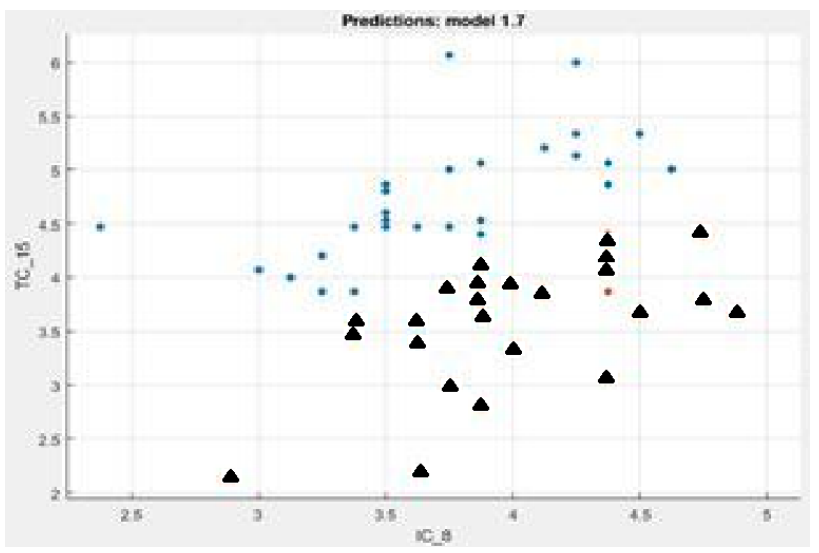

Şekil 3. IC ile TC Saçılma Diyagramı

Araştırma bulgularına göre tüketiciler sayısal bilgi tercihlerine ve duyusal bilgi tercihlerine göre ayrışmaktadırlar, saçılma diyagramları sayısal bilgi tercih edenler ile duyusal bilgi tercih edenlerin başarılı bir şekilde ayrıştığını göstermektedir. Makine öğrenmesi algoritmalarından Linear SVM araştırmada kullanılan diğer sınıflandırma algoritmalarına kıyasla en başarılı sınıflandırmayı yapmaktadır. Yani Linear SVM yöntemi ile \% 71,4 başarı oranı tüketiciler doğru grupta sınıflandırılabilmektedir, bu oran başarılı bir orandir.

\section{SONUÇ}

Ambalaj tasarımı günümüzde ürünün korunması amacını aşmıștır. Tüketiciler alışverişlerini yaparken ambalaj şirketin bir temsilcisi olarak rol oynamakta, ürünün tutundurmasını gerçekleștirmektedir. Başarılı bir ambalaj tasarımının hızlı tüketim ürünlerinde satışlar üzerinde etkisi olduğu bilinmektedir. Ancak her tüketici aynı değildir ve her tüketicinin bilgi arayışı da aynı değildir. Bu çalışmada tüketicilerin ambalajlarda 
yer alan bilgileri tercih etmeleri bakımından bir fark olduğu ve bu farkın sayısal bilgi ile duyusal bilgi olduğu varsayılmıştır. Tüketiciler makine öğrenmesi yöntemi ile sinıflandırılmaya çalışılmıştır.

Çalışmada 18 adet makine öğrenmesine dayalı büyük veri yöntemi kullanılarak tüketiciler sınıflandırılmaya çalışılmıștır. Bu çalışmada Linear Support Vector Machine (LSVM) yöntemi en iyi sonucu vermiștir. Uygulamada ambalaj tasarımcılarının hedef kitlelerinin bilgi ihtiyacı türünün belirlenmesi, ambalaj üzerinde yer alacak bilgilerin tasarlanmasında kullanılabilir. Linear SVM yönteminin bir diğer kullanım alanı görüntü işleme teknolojileridir. Linear SVM'nin bu özelliği ambalajların renklerinin tasarımı üzerinde de kullanılabileceği anlamına gelir.

Tüm ambalaj tasarımları genelde markalandırma, adlandırma, ürün çeşidi, yararları, ağırlık, özellikleri ve ölçüleri gibi çok az bilgi sunmaktadır. Çoğunlukla sayısal bilginin miktarı alan az olduğu için çok fazlaymış gibi görünür. Tasarımcı açısından bu bilginin ayırt edici şekilde görünmesi sağlanabildiğinde marka imgesi desteklenmiş olur ve söz konusu sayısal bilginin yararlı kılınması tüketicilerin talep ettikleri ürünü seçmelerini de kolaylaştırır. Tasarım aşamasında hedef tüketici kitlesi tarafından sayısal bilginin satın alma kararı anında, kullanım aşamasında ve satış sonrasında nasıl algıladığının bilinmesi önemlidir. Bu durumda yasalar veya tasarımcının yaratıcılık beceresi ile değil, tamamen müşteri psikolojisiyle ambalajı tasarlamak gerekmektedir. İnsan algısının ilkelerini yansıtan ve bunları kullanan ambalajlar başarılı olabilirler (Ak, 2009; Durmaz, 2009; Ježovičová, Turčínková \& Drexler, 2016; Örücü \& Tavşancl, 2011; Ramaprasad \& Hasegawa, 1992). Hedef kitlenin PNI ve TC eğilimlerinin belirlenmesi sayısal, sözlü veya grafiksel stiller gibi ürün bilgilerini sunma kararının verilmesinde ve pazarlama iletişimini geliştirmek amacıyla belirli pazar bölümlerini/segmentleri veya müşteri gruplarını tanımlamak için pazarlamacılar tarafından kullanılabilir.

Çalışmanın amacı, tüketicilerin sayısal bilgiyi tercih edenler ve duyusal bilgiyi tercih edenler olarak ikiye ayrıldıklarını ve makine öğrenmesi algoritmaları ile tüketicilerin segmentlere/pazar bölümlerine nasıl atanabileceğini göstermektir. Araştırma, ambalaj tasarımcılarına, ürün ve marka yöneticilerine, pazarlama ve reklam uzmanlarına ambalaj tasarlarken hedef kitlelerinin sayısal ve duyusal bilgi tercihlerini dikkate almaları gerektiğini ve bu ayrımın nasıl analiz edileceğini göstermektedir.

Ancak araştırma bulgularının belirli kısıtlar altında değerlendirilmesi gerekmektedir. $\mathrm{Bu}$ kısıtlardan ilki makine öğrenme yöntemlerinin deterministik olmamasıdır. Makine öğrenmesi rassal alt-örneklem seçme ve bu alt-örneklem ile veri setini karşılaştırmaya dayanmaktadır. Bu durum her defasında aynı sonucun bulunmasını engellemektedir. Bu sorunu çözmek amacıyla modellerin çok sayıda çalıştırılarak ortalamaları alınması bir çözümdür. Bir diğer önemli sorun çalışmanın sadece hızlı tüketim ürünlerinden tek bir ürünü incelemesidir. Daha fazla ürün grubu çalışmaya dahil edilebilir. Ancak çok sayıda ambalajın aynı modelde başka bir çözülmesi gereken sorun oluşturacaktır. Ambalaj tasarımlarının birbirine mümkün olduğu kadar yakın olması ile bu sorun çözülebilir.

\section{KAYNAKÇA}

AAKER, D. A. \& NORRIS, D. (1982). Characteristics of TV commercials perceived as informative. Journal of Advertising Research.

AK, T. (2009). Marka yönetimi ve tüketici karar sürecine etkileri. Karamanoğlu Mehmetbey Üniversitesi Sosyal Bilimler Enstitüsü,

ALKEN, L. R. (1974). Two scales of attitude toward mathematics. Journal for research in Mathematics Education, 67-71. 
Didem Tavlı, Mehmet Özer Demir, “Ambalaj Üzerindeki Sayısal ve Duyusal Bilgi Tercihlerine Göre Makine Öğrenmesi Yaklaşımı ile Tüketicilerin Sınıflandırılması”, İstanbul Gelişim Üniversitesi Sosyal Bilimler Dergisi, 8 (2), Ekim 2021, ss. 337-350.

ALKHATEEB, H. M. \& ABED, A. S. (2002). Factor structure of an Arabic translation of the scale, preference for numerical information. Perceptual and motor skills, 94(1), 185-188.

BAŞTÜRK, F., YILDIZ, S. \& INAN, P. (2014). Hazır gıda ürünleri satın alma davranışını etkileyen pazarlama faktörlerinin İncelenmesi: Iğdır İlinde bir araştırma. Çankırı Karatekin Üniversitesi IIIBF Dergisi, 4(1), 223-236.

BENDEGÜL, A. O. \& BULDUK, S. (2003). Tüketicilerin süpermarketlerdeki alışveriş alış̧anlıkları ve ürün seçimini etkileyen etmenler.

CAHYORINI, A. \& RUSFIAN, E. Z. (2012). The effect of packaging design on impulsive buying. Bisnis \& Birokrasi Journal, 18(1).

CARRILLO, E., VARELA, P. \& FISZMAN, S. (2012). Packaging information as a modulator of consumers' perception of enriched and reduced-calorie biscuits in tasting and non-tasting tests. Food Quality and Preference, 25(2), 105-115.

CHANDON, P. (2013). How package design and packaged-based marketing claims lead to overeating. Applied Economic Perspectives and Policy, 35(1), 7-31.

CLEMENT, J., SMITH, V., ZLATEV, J., GIDLÖF, K. \& VAN DE WEIJER, J. (2017). Assessing information on food packages. European Journal of Marketing, 51(1), 219-237. COWBURN, G. \& STOCKLEY, L. (2005). Consumer understanding and use of nutrition labelling: a systematic review. Public health nutrition, 8(1), 21-28.

CUI, G., LIU, H., YANG, X. \& WANG, H. (2013). Culture, cognitive style and consumer response to informational vs. transformational advertising among East Asians: Evidence from the PRC. Asia Pacific Business Review, 19(1), 16-31.

DILBER, F., DILBER, A. \& KARAKAYA, M. (2012). Godalarda ambalajın önemi ve tüketicilerin satın alma davranışlarına etkisi (Karaman ili örneği). Gümüşhane Üniversitesi İletişim Fakültesi Elektronik Dergisi, 1(3).

DURMAZ, Ö. (2009). Hızlı tüketim ürünlerinin ambalaj tasarımlarında çağrışımsal öğrenme ile renk kararları. DEÜ Güzel Sanatlar Enstitüsü,

DÜZ, N. (2012). Ambalaj-reklam ilişkisi ve tasarım eğitimindeki yeri.

EDELL, J. A. \& BURKE, M. C. (1987). The power of feelings in understanding advertising effects. Journal of Consumer research, 14(3), 421-433.

EREVELLES, S. (1998). The role of affect in marketing. Journal of Business Research, 42(3), 199-215.

FENNIS, B. M., DAS, E. \& FRANSEN, M. L. (2012). Print advertising: Vivid content. Journal of Business Research, 65(6), 861-864.

GAVILAN, D., AVELLO, M. \& ABRIL, C. (2014). The mediating role of mental imagery in mobile advertising. International Journal of Information Management, 34(4), 457-464.

GÖKALP, F. (2007). Gıda ürünleri satın alma davranışında ambalajın rolü. Ege Akademik Bakış Dergisi, 7(1), 79-97.

İLHAN, M. (2016). Türkiye'deki illerin tanıtımının bölgesel ürün ambalajlamasına göre incelenmesi. Medeniyet Sanat, 2(2), 105-120.

JEŽOVIČOVÁ, K., TURČÍNKOVÁ, J. \& DREXLER, D. (2016). The influence of package attributes on consumer perception at the market with healthy food. Acta Universitatis Agriculturae et Silviculturae Mendelianae Brunensis, 64(6), 1919-1926.

JU, I. \& PARK, J. S. (2015). Communication strategies in direct-to-consumer prescription drug advertising (DTCA): Application of the six segment message strategy wheel. Journal of health communication, 20(5), 546-554.

KIM, J. (2017). The influence of graphical versus numerical information representation modes on the compromise effect. Marketing Letters, 28(3), 397-409.

KING, S. C. \& MEISELMAN, H. L. (2010). Development of a method to measure consumer emotions associated with foods. Food Quality and Preference, 21(2), 168-177. 
Didem Tavlı, Mehmet Özer Demir, “Ambalaj Üzerindeki Sayısal ve Duyusal Bilgi Tercihlerine Göre Makine Öğrenmesi Yaklaşımı ile Tüketicilerin Sınıflandırılması”, İstanbul Gelişim Üniversitesi Sosyal Bilimler Dergisi, 8 (2), Ekim 2021, ss. 337-350.

KISS, A. (2018). Investigating young children's attitudes toward mathematics: Improved measurement and the relation to achievement.

KWONG, J. Y. \& WONG, K. F. E. (2006). The role of ratio differences in the framing of numerical information. International Journal of Research in Marketing, 23(4), 385-394.

LORD, K. R. \& PUTREVU, S. (2009). Informational and transformational responses to celebrity endorsements. Journal of Current Issues \& Research in Advertising, 31(1), 1-13.

MALIK, S. (2018). Subscales of undergraduates' attitudes toward mathematics: A quantitative investigation. Journal of Mathematics Education, 11(3), 1-32.

MiNA, M. S. (2017). Çikolata ve Gıda Ambalajı Tasarımında Resimlemenin Etkileri. Güzel Sanatlar Enstitüsü,

MÜDERRISOĞLU, F. (2009). Tüketici satın alma kararını etkileyen faktörler ve ailede satın alma kararının verilmesi: Pilot bir araştırma. Yayınlanmış Yüksek Lisans Tezi, Beykent Üniversitesi Sosyal Bilimler Enstitüsü.

ODUMERU, J. A., MITCHELL, S. J., ALVES, D. M., LYNCH, J. A., YEE, A. J., WANG, S. L., ... FARBER, J. M. (1997). Assessment of the microbiological quality of ready-to-use vegetables for health-care food services. Journal of Food Protection, 60(8), 954-960.

ÖRÜCÜ, E. \& TAVŞANCI, S. (2011). Gıda ürünlerinde tüketicinin satın alma eğilimini etkileyen faktörler ve ambalajlama. Sosyal ve Beşeri Bilimler Araştirmalari Dergisi, 1(3).

PERRY, V. G., MOTLEY, C. M. \& ADAMS Jr, R. L. (2016). What's the Point (s)? Information Content and Messaging Strategies in Mortgage Loan Advertisements. Cityscape, 18(2), 35-54.

PUTO, C. P. \& WELLS, W. D. (1984). Informational and transformational advertising: The differential effects of time. ACR North American Advances.

RAMAPRASAD, J. \& HASEGAWA, K. (1992). Informational content of American and Japanese television commercials. Journalism Quarterly, 69(3), 612-622.

SMITH, W. I. \& DRUMMING, S. T. (2004). Preference for numerical information and academic achievement of African-American students. Psychological reports, 95(2), 631-636.

TEK, Ö. B. (1999). Pazarlama ilkeleri: Global yönetimsel yaklaşım Türkiye uygulamalari: Beta.

TOPUZOĞLU, A., HIDIROĞLU, S., AY, P., ÖNSÜZ, F. \& İKIIŞIK, H. (2007).

Tüketicilerin gıda ürünleri ile ilgili bilgi düzeyleri ve sağlık risklerine karşı tutumları. TSK Koruyucu Hekimlik Bülteni, 6(4), 253-258.

UNDERWOOD, R. L. \& KLEIN, N. M. (2002). Packaging as brand communication: effects of product pictures on consumer responses to the package and brand. Journal of Marketing Theory and Practice, 10(4), 58-68.

VISWANATHAN, M. (1993). Measurement of individual differences in preference for numerical information. Journal of Applied Psychology, 78(5), 741.

VISWANATHAN, M. (1994). On the test-retest reliability of the Preference for Numerical Information scale. Psychological reports, 75(1), 285-286.

VISWANATHAN, M. (1996). A comparison of the usage of numerical versus verbal nutrition information by consumers. ACR North American Advances.

WISE, S. L. (1985). The development and validation of a scale measuring attitudes toward statistics. Educational and psychological measurement, 45(2), 401-405.

YAN, D. \& DUCLOS, R. (2013). Making sense of numbers: Effects of alphanumeric brands on consumer inference. International Journal of Research in Marketing, 30(2), 179-184. 
Didem Tavl, Mehmet Özer Demir, "Ambalaj Üzerindeki Sayısal ve Duyusal Bilgi Tercihlerine Göre Makine Öğrenmesi Yaklaşımı ile Tüketicilerin Sınıflandırılması”, İstanbul Gelişim Üniversitesi Sosyal Bilimler Dergisi, 8 (2), Ekim 2021, ss. 337-350.

\section{Summary}

The packaging presents the product at the point of purchase for the consumer and ensures that the product is promoted in the market. Industrial manufacturers have discovered that they can pack their products in an attractive way for traders to sell, and they have begun to use the packaging for this purpose. Today, products placed in supermarket shelves cannot be sold without packaging. The packaging also serves to communicate with the consumer. This communication can only be established through the information function of packaging. While the information on the package consists of logically sound words and numbers, the other sensory dimension includes shapes, colors, and graphics which addresses directly to emotions, bypassing the logic level.

This study assumes that consumers can be divided according to their preference for numerical information and transformational content. The study operationalizes the preference for numerical information scale and informal and transformational ad content scales. The study aims to classify consumers using machine learning methods according to numerical or sensory information preferences. Preference for numerical information is a structure that measures the tendency to use, understand, and interpret numerical information. Every package contains a piece of information on it, which gives an idea about the brand. The information on the packaging can be divided into two; informational content and sensory/transformational content. The purpose of informative information available on the packaging is to inform the consumer, however, if the targeted consumers can understand and interpret numerical informative information the aim is achieved. Therefore, it is not the information on the packaging that matters, but the amount and type of information consumers are aware of, understand, and/or interpret.

In the study, sample selection was made using the judgment sampling method. The researchers aimed to balance the two types of participants. Machine learning algorithms, one of the big data methods, were used in the analyses. In the analysis, $25 \%$ of the data from the data set was used in machine learning, \%75 for control. The study aims to find the machine learning analysis method that best classifies consumers according to their preferences. The findings suggest that Linear Support Vector Machine was the best classification method among the 18 machine learning algorithms. The Linear SVM method estimates $70 \%$ correct the consumers who respond to the questionnaire containing the graphic packaging, and 30\% in the wrong class, whereas LVSM estimate 73\% correct the respondents of the package containing the numerical content, and $27 \%$ wrong.

In this study, it is assumed that consumers can be segmented according to their numerical and transformational content preferences. The findings suggest that machine learning algorithms can be used to segment consumers based on PNI and TC. findings of the study can be used for packaging designs. 
Didem Tavl, Mehmet Özer Demir, "Ambalaj Üzerindeki Sayısal ve Duyusal Bilgi Tercihlerine Göre Makine Öğrenmesi Yaklaşımı ile Tüketicilerin Sınıflandırılması", İstanbul Gelişim Üniversitesi Sosyal Bilimler Dergisi, 8 (2), Ekim 2021, ss. 337-350.

Ek 1: Ankette Kullanılan Ambalaj Tasarımları

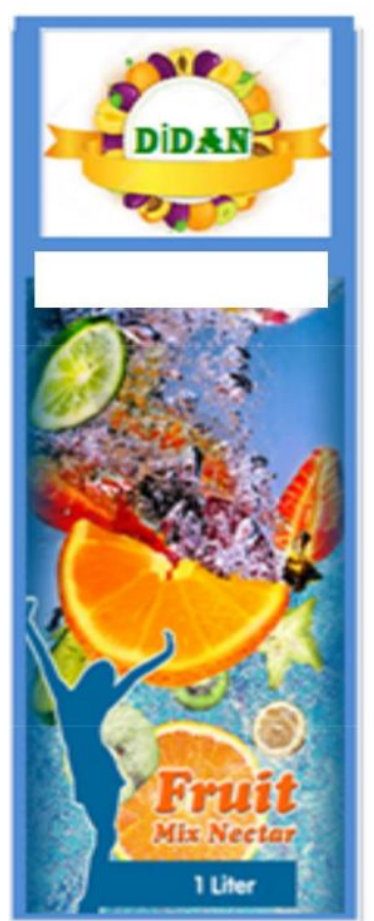

KARIŞIK MEYVE SUYU

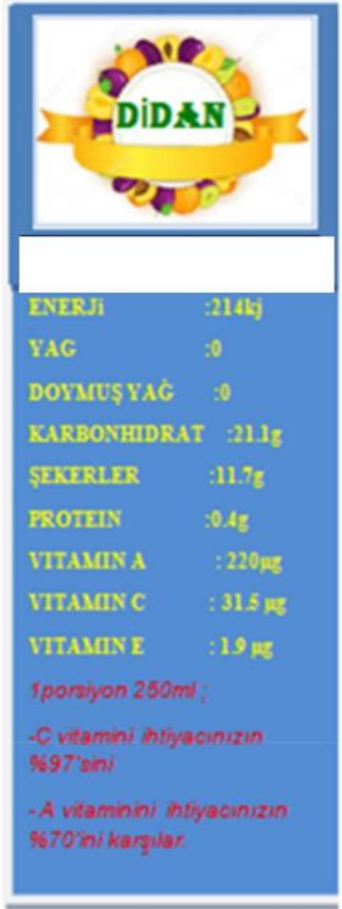

KARIŞIK MEYVE SUYU 